\title{
Pneumatization of the Frontal and Sphenoid Sinus in Korean Adults: A Study of Using Computed Tomography Scans
}

\author{
Young Chang Sim, Myeongsin Kang, Joon Sang Yu, and Jae Hoon Lee \\ Department of Otolaryngology-Head and Neck Surgery, Institute of Wonkwang Medical Science, School of Medicine, \\ Wonkwang University, Iksan, Korea
}

\section{한국인 성인에서의 전두동과 접형동의 함기화: 전산화단층촬영을 이용한 연구}

심영창 - 강명신 · 유준상 · 이재훈

원광대학교 의과대학 이비인후과학교실

Received September 30, 2017

Revised November 16, 2017

Accepted November 21, 2017 Address for correspondence Jae Hoon Lee, MD, PhD Department of OtolaryngologyHead and Neck Surgery, Institute of Wonkwang Medical Science, School of Medicine, Wonkwang University, 895 Muwang-ro, Iksan 54538, Korea Tel $+82-63-859-1441$

Fax $+82-63-841-6556$

E-mail Leejaehoon64@gmail.com
Background and Objectives For safe sinus surgery, it is essential to understand the anatomical structure and developmental state of the paranasal sinuses. Structural abnormalies such as aplastic and marked hypoplastic sinuses may not be amenable to sinus surgery or balloon sinuplasty. The purpose of this study is to evaluate the degree of pneumatization of the frontal and sphenoid sinuses in Korean adults.

Subjects and Method This retrospective study utilized CT images of 1190 sides from 595 Korean adults. The frontal sinus was classified into normal, hypoplasia, aplasia and unilateral hidden aplasia. The sphenoid sinus was evaluated the incidence regarding the aplasia and unilateral hidden hypoplasia.

Results Bilateral frontal sinus hypoplasia was observed in $8.5 \%$ of women and $4.2 \%$ of men $(p<0.05)$, while unilateral frontal sinus hypoplasia was found in $3.5 \%$ of women and in $4.8 \%$ of men $(p>0.05)$. Bilateral frontal sinus aplasia was observed in $7.1 \%$ of women and $2.9 \%$ of men $(p<0.05)$, while unilateral frontal sinus aplasia were found in $7.1 \%$ of women and in $5.4 \%$ of men $(p>0.05)$. Unilateral hidden frontal sinus aplasia was observed in $1.7 \%$ of women and $1.5 \%$ of men $(p>0.05)$. There was no bilateral sphenoid sinus aplasia and only one woman had unilateral sphenoid sinus aplasia. Unilateral hidden sphenoid sinus hypoplasia was observed in $1.4 \%$ of women and $2.9 \%$ of men ( $p>0.05)$.

Conclusion Bilateral frontal sinus hypoplasia and aplasia are more common in women than in men. Although the incidences of unilateral hidden frontal sinus aplasia and hidden sphenoid sinus hypoplasia are low, sinus surgeons should carefully review CT for sinus surgery or balloon sinuplasty.

Korean J Otorhinolaryngol-Head Neck Surg 2018;61(7):349-54

Key Words Aplasia · Computed tomography scan · Frontal sinus · Hypoplasia · Sphenoid sinus.

\section{서 론}

만성 부비동염의 수술적 치료로 내시경수술과 더불어 풍 선카테터 부비동확장술(balloon sinuplasty)이 많이 시행되고
있다. 내시경수술 혹은 풍선카테터 부비동확장술을 이용한 전두동과 접형공 자연공 확장술을 안전하게 시행하는 데 해 부학적 구조의 이해뿐만 아니라 전두동과 접형동의 발육 상 태의 파악이 필수적이다.

This is an Open Access article distributed under the terms of the Creative Commons Attribution Non-Commercial License (https://creativecommons.org/licenses/by-nc/4.0) which permits unrestricted non-commercial use, distribution, and reproduction in any medium, provided the original work is properly cited. 
전두동의 발육 상태는 무형성, 발육저하, 정상발육으로 분 류할 수 있고, 양측 혹은 일측으로 구분할 수 있다. 또한 최근 숨겨진 편측 전두동 무형성(hidden unilateral agenesis of the frontal sinus)에 대한 연구가 보고되었다. ${ }^{1,2)}$ 숨겨진 편측 전두 동 무형성은 일측성 전두동 무형성과 동시에 반대측 전두동 이 무형성된 쪽으로 과도하게 함기화되어 있는 상태로 CT에 서 양측 전두동이 정상발육 상태로 오인할 수 있어 내시경 전 두동 수술 및 풍선카테터 부비동확장술 수술 때 각별히 주 의를 요한다.

접형동은 접형골의 함기화된 공간으로서 대부분 쌍으로 존재하고 좌우 비대칭적으로 발달되며 일반적으로 conchal, presellar, sellar 형태의 세 가지로 분류할 수 있다. 첫째, conchal 형태로 함기화가 매우 적을 때로 터키안 전방에 위치하며 두꺼운 골조직에 의해 터키안과 분리되어 있다. 둘째, presellar 형태로 터키안 전방까지 함기화된 경우이며, 셋째, sellar, postsphenoid 혹은 occipital 형태로 함기화가 터키안 후방까 지 함기화된 상태를 말한다. 전두동과는 달리 접형동에서 양 측 혹은 일측 무형성은 매우 드문 것으로 알려져 있다. ${ }^{4}$ 일측 접형동의 심한 발육저하는 반대측의 접형동이 발육저하된 접형동 쪽으로 지나치게 함기화가 되어 CT에서 양측 접형동 정상발육 상태로 오인할 수 있다. 이런 경우를 숨겨진 편측 전 두동 무형성을 보고한 연구1,2)를 참고하여 저자들은 숨겨진 편 측 접형동 발육저하(hidden unilateral hypoplasia of the sphenoid sinus)로 명칭하였다.

이에 저자들은 multiplanar CT reconstruction(MPR)을 이 용하여 한국인 정상 성인 남녀 595명을 대상으로 전두동을 무형성, 발육저하로 분류하고, 숨겨진 편측 전두동 무형성의 빈도를 얻고자 하였다. 접형동은 무형성 및 숨겨진 편측 접형 동 발육저하의 빈도를 얻고자 하였다.

\section{대상 및 방법}

대 상

2012년 1월부터 2013년 12월까지 본 병원에 내원하여 부비 동 전산화단층촬영을 했던 20세에서 70세까지 총 595명을 대상으로 연구를 수행하였다. 대상군은 남자는 313명, 평균 나이는 43.2 \pm 13.6 세, 여자는 282 명, 평균나이는 $47.3 \pm 12.7$ 세 였다. 연구 수행에 혼돈을 줄 수 있는 과거 코 수술 기왕력, 안면외상, 전두와와 전두동, 접형동에 종양성 병변과 낭종성 병변이 있는 경우는 제외하였다. 본 연구는 원광대학교병원 임 상시험심사위원회 심의면제(WKUH 1783)를 받은 후 진행되 었다.

\section{고해상력 부비동 단층촬영을 통한 분석}

연구대상군인 595명의 좌우 1190 측을 부비동 전산화단층 촬영을 통해 분석하였다. 단층촬영은 Somatom Definition Flash 256-slice CT scanners(Simens Healthcare, Forchheim, Germany)를 이용하여 $1 \mathrm{~mm}$ 두께로 축상면을 구성하여 이 를 통해 MPR 하였다.

전두동 발육 상태는 정상, 발육저하, 무형성, 그리고 양측 혹은 일측으로 구분하였고, 일측 무형성인 경우 숨겨진 일측 전두동 무형성인지 주의 깊게 확인하였다. 첫째, 전두동 무형 성은 전두동의 발육 상태가 안와의 상벽(orbital roof) 위로 전 혀 함기화가 되지 않는 경우로 하였고(Fig. 1), 둘째, 발육부전 은 과거 연구 ${ }^{5}$ 에서의 방법을 참고하여 전두동이 안와의 상벽 위로 함기화는 되었으나 볏돌기(crista galli)를 기준으로 외 측 $15 \mathrm{~mm}$ 이내에서 전두동의 깊이 측정이 불가능한 경우로 하였다. 셋째, 숨겨진 일측 전두동 무형성은 반대측 전두동이 과도하게 함기화되어 무형성된 측의 지판(lamina papyracea)
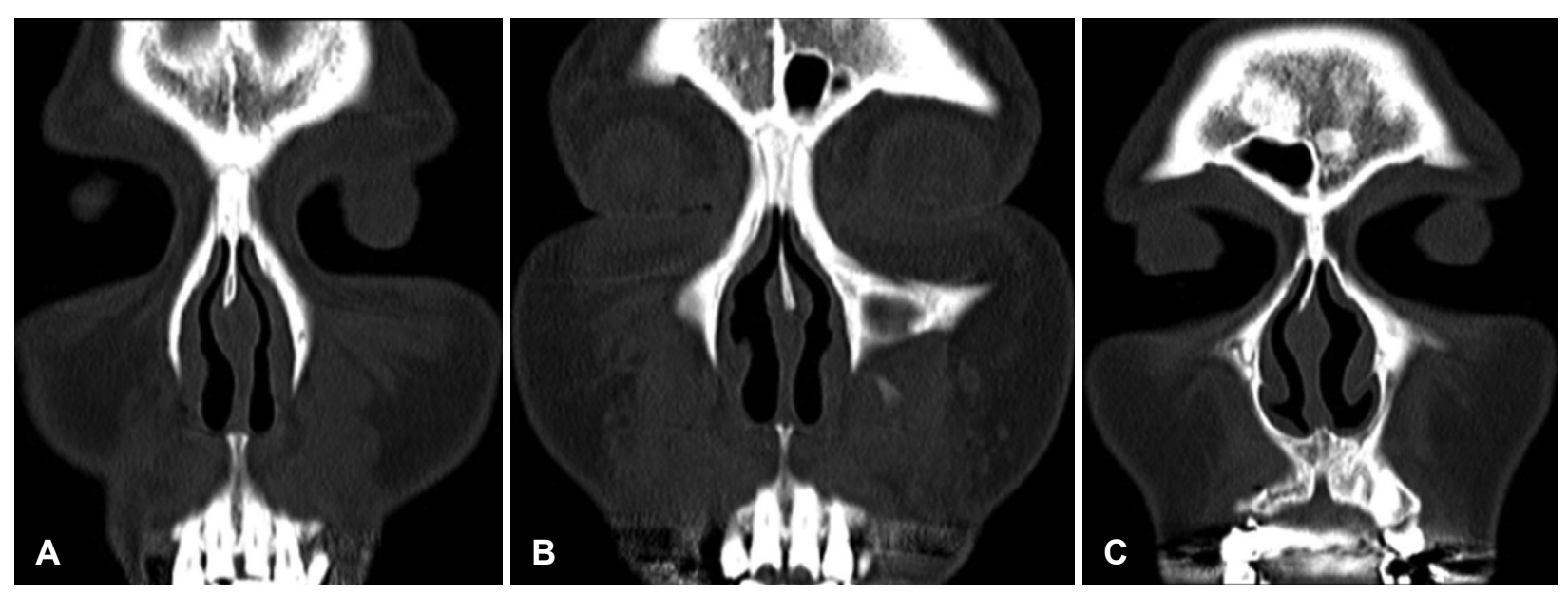

Fig. 1. Coronal computed tomography image of the paranasal sinuses. The image shows bilateral frontal sinus aplasia (A), right frontal sinus aplasia (B), and left frontal sinus aplasia (C). 
을 넘어서는 경우로 하였다(Fig. 2)

접형동에 대한 연구는 발육이 전혀 되지 않은 경우와 숨겨 진 일측 접형동 발육저하의 빈도를 확인하였다. 첫째, 접형동 무형성은 conchal 형태와 혼돈을 피하기 위해 CT의 축상면, 관상면 영상을 통해 접형동의 무형성을 확인하였다(Fig. 3).
둘째, 숨겨진 일측 접형동 발육저하는 반대측 접형동이 과도 하게 함기화되어 발육저하된 접형동의 외측벽까지 함기화된 경우로 하였다(Fig. 4).

판정 오류를 막기 위해 2 명의 관찰자에 의해 각각 수행되 었으나 의견의 일치가 되지 않은 예의 경우 제삼자에게 의뢰
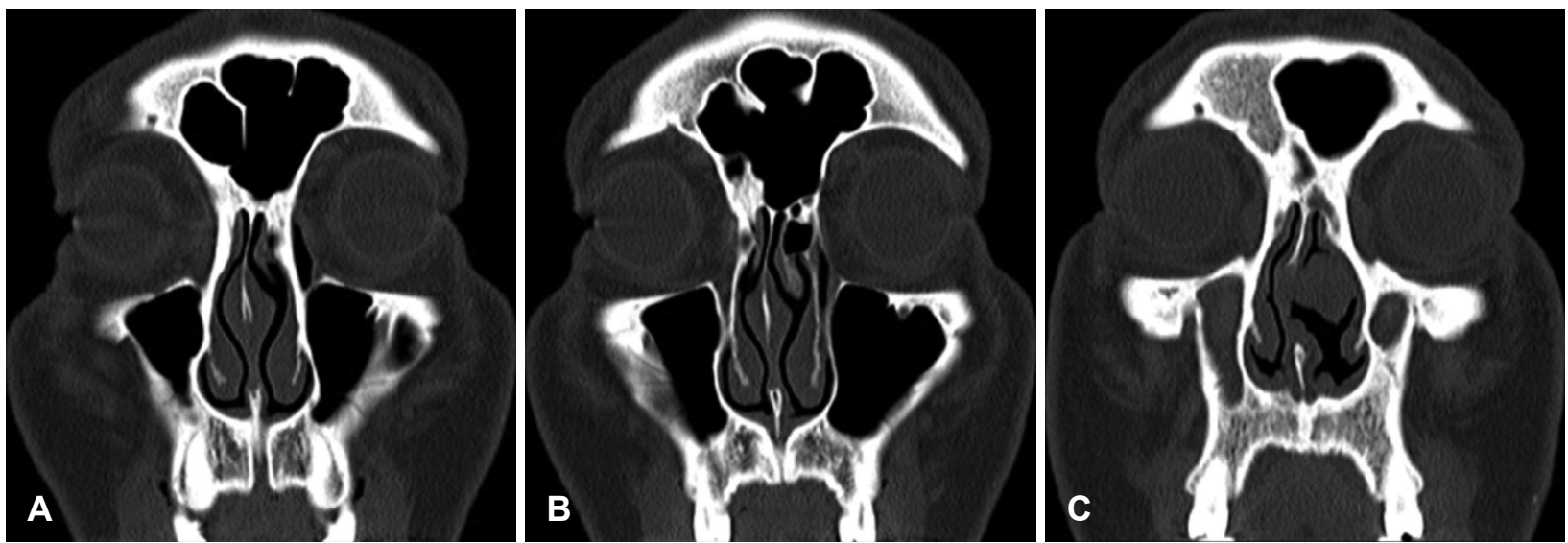

Fig. 2. Coronal computed tomography images of the paranasal sinuses. Right hidden unilateral aplasia of the frontal sinus (A and $B$ ). Images $A$ and $B$ are belonged to the same person and B is the following image of A. Hidden unilateral aplasia of the frontal sinus is described as the absence of one of the frontal sinuses with increased pneumatization of contralateral sinus toward the aplastic side. These images ( $A$ and $B$ ) show right frontal sinus aplasia with increased pneumatization of the left frontal sinus beyond the right lamina papyracea on the side of aplastic sinus. An example of the non-hidden unilateral aplasia of the frontal sinus (C).

Fig. 3. Coronal (A) and axial (B) computed tomography images of the paranasal sinuses. The images show right aplasia of the sphenoid sinus.
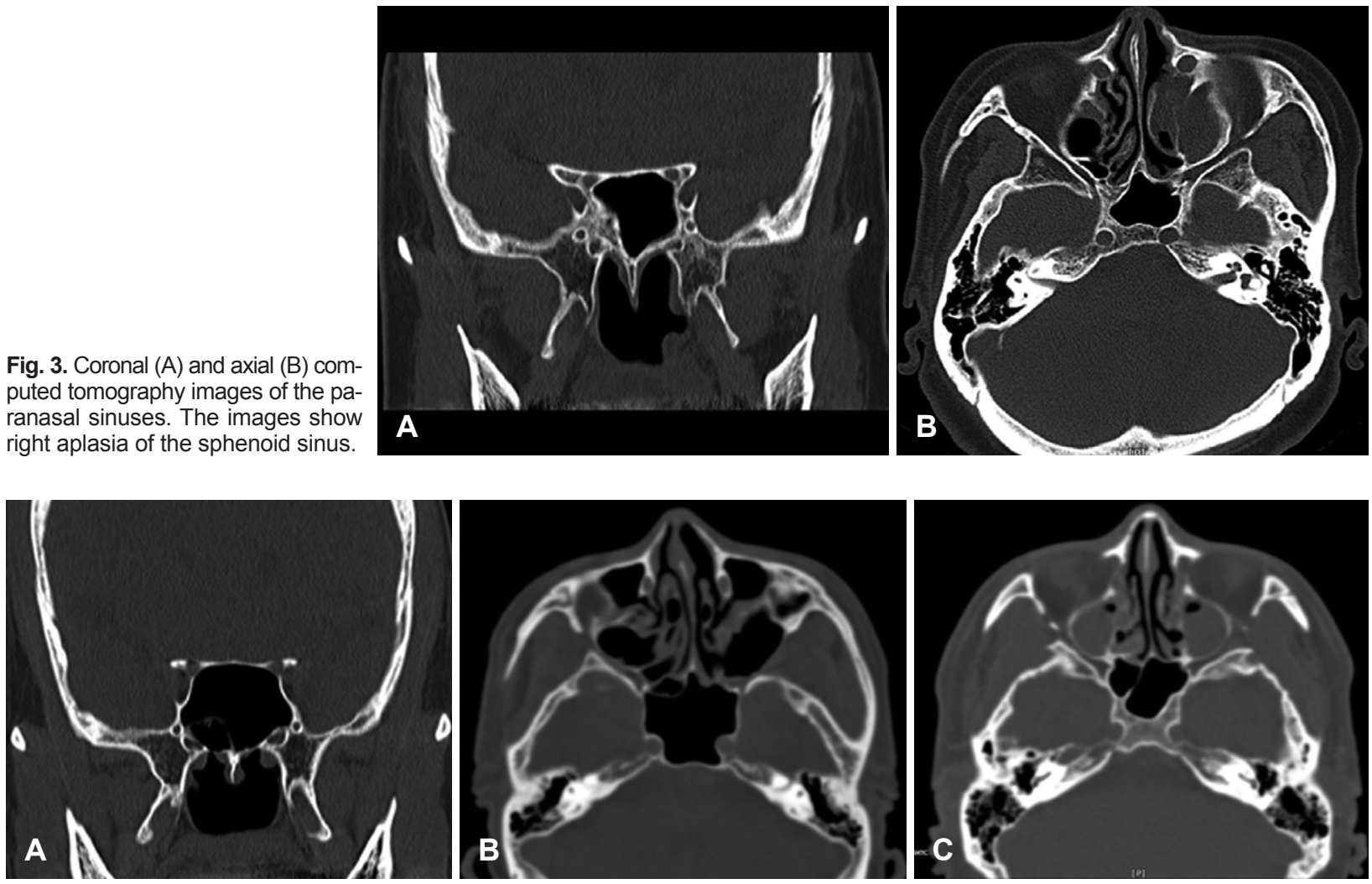

Fig. 4. Computed tomography images of the paranasal sinuses. The coronal (A) and axial (B) images show right hidden unilateral hypoplasia of the sphenoid sinus. Hidden unilateral hypoplasia of the sphenoid sinus is described as the hypoplasia of one of the sphenoid sinuses with increased pneumatization of contralateral sinus toward the hypoplastic side. An example of the non-hidden unilateral hypoplasia of the sphenoid sinus (C). 
Table 1. Frequency of frontal sinus hypoplasia in Korean adult individuals

\begin{tabular}{|c|c|c|c|c|c|}
\hline \multirow{3}{*}{ Sex } & \multicolumn{5}{|c|}{ Frontal sinus hypoplasia } \\
\hline & \multirow{2}{*}{ Bilateral (\%) } & \multicolumn{3}{|c|}{ Unilateral } & \multirow{2}{*}{ Total $(\%$} \\
\hline & & Right & Left & Total (\%) & \\
\hline Female & $24(8.5)$ & 4 & 6 & $10(3.5)$ & $34(12.0)$ \\
\hline Male & $13(4.2)$ & 13 & 2 & $15(4.8)$ & $28(8.9)$ \\
\hline Total & $37(6.2)$ & 17 & 8 & $25(4.2)$ & $62(10.4)$ \\
\hline
\end{tabular}

Table 2. Frequency of frontal sinus aplasia in Korean adult individuals

\begin{tabular}{|c|c|c|c|c|c|}
\hline \multirow{3}{*}{ Sex } & \multicolumn{5}{|c|}{ Frontal sinus aplasia } \\
\hline & \multirow{2}{*}{ Bilateral (\%) } & \multicolumn{3}{|c|}{ Unilateral } & \multirow{2}{*}{ Total (\%) } \\
\hline & & Right & Left & Total (\%) & \\
\hline Female & $20(7.1)$ & 7 & 8 & $15(5.3)$ & $35(12.4)$ \\
\hline Male & $9(2.9)$ & 14 & 3 & $17(5.4)$ & $26(8.3)$ \\
\hline Total & $29(4.9)$ & 21 & 11 & $32(5.4)$ & $61(10.3)$ \\
\hline
\end{tabular}

Table 3. Frequency of hidden unilateral frontal sinus aplasia in Korean adult individuals

\begin{tabular}{lccr}
\hline \multicolumn{1}{c}{ Sex } & Right & Left & Total $(\%)$ \\
\hline Female & 5 & 0 & $5(1.7)$ \\
Male & 3 & 2 & $5(1.5)$ \\
\hline Total & 8 & 2 & $10(1.6)$ \\
\hline
\end{tabular}

Table 4. Frequency of hidden unilateral sphenoid sinus hypoplasia in Korean adult individuals

\begin{tabular}{lccr}
\multicolumn{1}{c}{ Sex } & Right & Left & Total $(\%)$ \\
\hline Female & 2 & 2 & $4(1.4)$ \\
Male & 4 & 5 & $9(2.9)$ \\
\hline Total & 6 & 7 & $13(2.2)$ \\
\hline
\end{tabular}

하였으며 합일된 의견을 도출하였다.

\section{통 계}

통계학적 분석은 SPSS version 12.0 program(SPSS Inc., Chicago, IL, USA)을 이용하여 성별 비교에는 chi-square test, Fisher's exact test를 사용하였다. 유의성은 $p$ 값이 0.05 미만인 경우에 통계적으로 유의하다고 판정하였다.

\section{결 과}

\section{한국인 성인에서의 전두동 발육저하(Table 1)}

여성에서 양측성인 경우는 24 명 $(8.5 \%)$ 이었고, 남성에서는 13 명(4.2\%)이었고 전체 연구대상인 595명 중 37명(6.2\%)이었 다. 여성에서 남성보다 높게 나왔는데, 이는 통계학적으로 유 의한 차이를 보였다 $(p=0.028)$. 일측성인 경우 여성에서 우측 4 명, 좌측 6 명으로 총 10 명(3.5\%), 남성에서 우측 13 명, 좌측 2 명으로 총 15 명 $(4.8 \%)$ 이었다. 전체 연구대상인 595명 중 25명 (4.2\%)이었고, 여성과 남성 간에 유의한 차이는 없었다 $(p>$
0.05). 양측성과 일측성의 전두동 발육저하를 합한 경우는 여 성에서 34명(12.0\%), 남성에서 28명(8.9\%)으로 총 62명(10.4\%) 이었으며 여성과 남성 간에 유의한 차이는 없었다 $(p>0.05)$.

한국인 성인에서의 전두동 무형성(Table 2)

여성에서 양측성인 경우는 20명(7.1\%)이었고, 남성에서는 9 명(2.9\%)이었고 전체 연구대상인 595명 중 29명(4.9\%)이었 다. 여성에서 남성보다 높게 나왔는데, 이는 통계학적으로 유 의한 차이를 보였다 $(p=0.017)$. 일측성인 경우 여자에서 우측 7 명, 좌측 8 명으로 총 15 명(5.3\%), 남성에서 우측 14 명, 좌측 3 명으로 총 17명(5.4\%)이었다. 전체 연구대상인 595명 중 32명 (5.4\%)이었고, 여성과 남성 간에 유의한 차이는 없었다 $(p>$ 0.05). 양측성과 일측성의 전두동 무형성을 합한 경우는 여성 에서 35명(12.4\%), 남성에서 26명(8.3\%)이었고, 총 61명(10.3\%) 이었으며 여성과 남성 간에 유의한 차이는 없었다 $(p>0.05)$.

\section{한국인 성인에서의 숨겨진 일측 전두동 무형성(Table 3)}

여성인 경우 우측 5명, 좌측은 없었으며 총 5명(1.7\%), 남성 인 경우 우측 3 명, 좌측 2 명으로 총 5 명 $(1.5 \%)$ 이었다. 전체 연 구대상인 595명 중 10명(1.6\%)이었고, 여성과 남성 간에 유의 한 차이는 없었다 $(p>0.05)$.

\section{한국인 성인에서의 접형동 무형성}

양측성인 경우는 여성과 남성에서 관찰되지 않았다. 일측 성인 경우 여성 1 명의 우측에서 유일하게 관찰되었으며, 전체 연구대상인 595명 중 1 명(0.2\%)이었다.

한국인 성인에서의 숨겨진 일측 접형동 발육저하(Table 4) 여성에서 우측 2 명, 좌측 2 명으로 총 4 명(1.4\%), 남성에서 
우측 4명, 좌측 5 명으로 총 9 명(2.9\%)이었다. 전체 연구대상 인 595명 중 13명(2.2\%)으로 남성에서 약간 높았으나 여성과 남성 간에 유의한 차이는 없었다 $(p>0.05)$.

\section{고 찰}

전두동은 전두골이 함기화된 것으로 태생 전두와에서 기원 하거나 사골누두의 전상방, 상사골포 봉소(suprabullar cell) 확장에 의해 발생하며, 출생 시 전두동의 전구체라 할 수 있는 2 3개의 봉소가 관찰된다. ${ }^{6}$ 생후 18 20개월경 전두골의 수 직판 내로 자라 올라가며 전두동은 7 9세가 되어야 방사선 적 검사에서 확인 가능하며 20세까지 함기화가 진행된다. ${ }^{7)}$ 전두동의 크기는 매우 다양하며, 전두동의 높이는 5 66 $\mathrm{mm}$ (평균 $24.3 \mathrm{~mm}$ )이고 중앙선에서 측벽까지의 거리가 17 49 $\mathrm{mm}$ (평균 $29 \mathrm{~mm}$ )이다. ${ }^{6}$ ) 전두동을 좌우로 나누는 전두동 중 격은 정중앙에 위치하지 않을 수 있으며, 약 9\%에서는 불완 전하게 형성된다.

성별, 인종, 지역에 따라 전두동 발달에 차이를 보일 수 있 는데 양측 전두동의 무형성은 연구자에 따라 1.3 43.0\%까지 다양하게 보고되었다. 알래스카 에스키모인 ${ }^{8}$ 의 경우 남성에 서 $25.0 \%$, 여성에서 $36.0 \%$, 캐나다 에스키모인 ${ }^{9}$ 의 경우 남성에 서 $43.0 \%$, 여성에서 $40.0 \%$, 같은 일본인을 대상으로 Yoshino 등 ${ }^{10)}$ 은 남성에서 $4.8 \%$, Ikeda ${ }^{11)}$ 는 남성에서 $13.0 \%$, 여성에서 $23.0 \%$ 로 보고하였고, 터키인 ${ }^{12)}$ 의 경우 남성 $1.3 \%$, 여성 $5.1 \%$ 로 보고되었다. 성별과 인종에 따른 차이뿐만 아니라 같은 인 종이라 하여도 거주 지역에 따라 차이를 보였고, 같은 인종과 비슷한 거주 지역이라도 연구자에 따라 차이를 보였다. 저자 들의 연구에서는 남성 $2.9 \%$, 여성 $7.1 \%$ 로 관찰되었다.

일측성 전두동 무형성은 연구자에 따라 0.8 14.3\%까지 다 양하게 보고되었다. Yoshino 등 ${ }^{10}$ 은 남성 $14.3 \%$, 여성 $7.1 \%$, Aydinlioğlu 등 ${ }^{12)}$ 은 남성 3.8\%, 여성 5.9\%, Schuller ${ }^{13)}$ 는 전체 적으로 $1.0 \%$ 로 보고하였다. 저자들의 연구에서는 남성 $5.4 \%$, 여성 $5.3 \%$ 로 관찰되었다.

저자들은 한국인을 대상으로 양측 혹은 일측 전두동의 무 형성의 빈도뿐만 아니라 숨겨진 편측 전두동 무형성의 빈도 를 알아보았다. 숨겨진 편측 전두동 무형성은 일측성 전두동 무형성와 동시에 반대측 전두동이 무형성된 쪽으로 과도하게 함기화되어 있는 상태로 $\mathrm{CT}$ 에서 양측 전두동이 정상발육 상태로 오인할 수 있어 내시경 전두동 수술 및 풍선카테터 부비동확장술 수술 때 각별히 주의를 요한다. Ozgursoy 등ㄹ 은 55구 카데바 연구에서 2구에서 숨겨진 일측 전두동 무형 성을 보고하였고, Gotlib 등른 305 명의 CT를 통해 숨겨진 일측 전두동 무형성은 총 11 명(3.6\%)으로 우측 6 명, 좌측 5 명
이었고, 남성 6 명, 여성 5 명에서 관찰하였다. 이번 연구에서는 595 명의 CT를 통해 숨겨진 우측 전두동 무형성을 총 10명 (1.6\%)으로 우측 8명, 좌측 2명이었고, 남성 5명, 여성 5명에 서 관찰되었으며 Gotlib 등'이 관찰한 빈도보다는 약간 적었 으며 좌우 간에 차이를 보였다. 저자들은 Gotlib 등릐 읜구 에서와 같이 숨겨진 일측 전두동 무형성의 기준을 반대측 전 두동이 과도하게 함기화되어 무형성된 측의 지판을 넘어서는 경우로 한정하여 연구를 진행하였다.

접형동은 비강측벽이 외측으로 확장하여 발생하는 다른 부비동들과는 차이를 보이는데 태생기 4개월에 비낭(nasal capsule)의 후단에서 발생하는 유일한 부비동이므로 독특한 발생 형태를 갖는다. ${ }^{14)}$ 출생 직후 $0.5 \times 2 \times 2 \mathrm{~mm}$ 의 미세한 공 간을 형성하고 접형골의 융합과 함기화에 따라 후측방으로 확장됨에 따라 12 세가 되어서 $14 \times 14 \times 12 \mathrm{~mm}$ 로 성인 크기에 이르게 된다. ${ }^{15)}$ 경우에 따라 접형동의 함기화가 접형골 체부 를 넘어 접형골의 대익, 소익, 내측 및 외측 익돌판, 후두골과 사골까지 진행하기도 한다.

접형동의 무형성은 매우 드물다. ${ }^{16-25)} 20$ 세기 전반기의 연구 에서 접형동의 무형성 발생빈도는 1 1.5\%로 보고되었는데 대 부분 CT 기반의 연구는 아니어서 함기화가 매우 적은 conchal 형태와 혼돈한 결과로 여겨진다. 접형동의 무형성은 두개골 조기봉합(craniosynostosis), 골이형성증(osteodysplasia), Down 증후군, Hand-Schuller-Christian 질환 등에서 발생 될 수 있다. ${ }^{426)} \mathrm{CT}$ 를 기반으로 한 연구에서 지금까지 양측 접 형동의 무형성은 13 예, ${ }^{16-24)}$ 일측 접형동의 무형성은 8예 ${ }^{23,25,26)}$ 로 매우 드물다. 저자들의 이번 연구에서도 595명 중 양측 접 형동의 무형성은 관찰할 수 없었고 일측 접형동의 무형성도 1 예 $(0.2 \%)$ 로 매우 드물었다. 숨겨진 일측 접형동 발육저하는 총 13명(2.2\%)으로 남성 9명, 여성 4명이었고 우측 6명, 좌측 7명에서 관찰되었다.

이번 연구는 한국인 성인을 대상으로 한 결과이며, 숨겨진 일측성 전두동 무형성과 숨겨진 일측성 접형동 발육저하의 발 생 빈도가 낮지만 전두동과 접형동 수술 때, 수술 전 주의 깊 은 $\mathrm{CT}$ 관찰이 필요할 수 있다.

\section{REFERENCES}

1) Ozgursoy OB, Comert A, Yorulmaz I, Tekdemir I, Elhan A, Kucuk B. Hidden unilateral agenesis of the frontal sinus: human cadaver study of a potential surgical pitfall. Am J Otolaryngol 2010;31(4): 231-4.

2) Gotlib T, Kuźmińska M, Held-Ziółkowska M, Osuch-Wójcikiewicz E, Niemczyk K. Hidden unilateral aplasia of the frontal sinus: a radioanatomic study. Int Forum Allergy Rhinol 2015;5(5):441-4.

3) Hammer G, Rådberg C. The sphenoidal sinus. An anatomical and roentgenologic study with reference to transsphenoid hypophysectomy. Acta Radiol 1961;56:401-22.

4) Uzun L, Sagun OF, Seferoglu B, Etlik O, Mahmutyazicioglu K. 
The significance of magnetic resonance imaging and computed tomography findings in sphenoid sinus agenesis. Ear Nose Throat $\mathrm{J}$ 2014;93(2):71-4.

5) Yoo SW, Lee JH. A measurement of the frontal sinus depth of Korean adults using the axial images of computed tomography. J Rhinol 2014;21(2):108-11.

6) Donald PJ, Gluckman JL, Rice DH. The sinuses. New York: Raven Press;1995. p.41-4.

7) Harris AM, Wood RE, Nortjé CJ, Thomas CJ. Gender and ethnic differences of the radiographic image of the frontal region. J Forensic Odontostomatol 1987;5(2):51-7.

8) Koertvelyessy T. Relationships between the frontal sinus and climatic conditions: a skeletal approach to cold adaptation. Am J Phys Anthropol 1972;37(2):161-72.

9) Hanson CL, Owsley DW. Frontal sinus size in Eskimo populations. Am J Phys Anthropol 1980;53(2):251-5.

10) Yoshino M, Miyasaka S, Sato H, Seta S. Classification system of frontal sinus patterns by radiography. Its application to identification of unknown skeletal remains. Forensic Sci Int 1987;34(4):289-99.

11) Ikeda J. Interpopulation variations of the frontal sinus measurements: comparison between the Jomon and recent Japanese population. J Anthrop Soc Nippon 1982;90:91-103.

12) Aydinlioğlu A, Kavakli A, Erdem S. Absence of frontal sinus in Turkish individuals. Yonsei Med J 2003;44(2):215-8.

13) Schuller A. A note on the identification of skulls by X-ray pictures of the frontal sinuses. Med J Aust 1943;1:554-6.

14) Maran AGD, Lund VJ. Clinical rhinology. New York: Thieme;1990. p.1-23.

15) Anderhuber W, Weiglein A, Wolf G. [Nasal cavities and paranasal sinuses in newborns and children]. Acta Anat (Basel) 1992;144(2):
$120-6$.

16) Antoniades K, Vahtsevanos K, Psimopoulou M, Karakasis D. Agenesis of sphenoid sinus. Case report. ORL J Otorhinolaryngol Relat Spec 1996;58(6):347-9.

17) Degirmenci B, Haktanir A, Acar M, Albayrak R, Yücel A. Agenesis of sphenoid sinus: three cases. Surg Radiol Anat 2005;27(4):351-3.

18) Keskin G, Ustündag E, Ciftçi E. Agenesis of sphenoid sinuses. Surg Radiol Anat 2002;24(5):324-6.

19) Anik I, Anik Y, Koc K, Ceylan S. Agenesis of sphenoid sinuses. Clin Anat 2005;18(3):217-9.

20) Haktanir A, Acar M, Yucel A, Aycicek A, Degirmenci B, Albayrak R. Combined sphenoid and frontal sinus aplasia accompanied by bilateral maxillary and ethmoid sinus hypoplasia. Br J Radiol 2005; 78(935):1053-6.

21) Orhan M, Govsa F, Saylam C. A quite rare condition: absence of sphenoidal sinuses. Surg Radiol Anat 2010;32(6):551-3.

22) Güven DG, Yilmaz S, Ulus S, Subaşi B. Combined aplasia of sphenoid, frontal, and maxillary sinuses accompanied by ethmoid sinus hypoplasia. J Craniofac Surg 2010;21(5):1431-3.

23) Sonbay D, Saka C, Akin I, Gunsoy B, Gokler A. Prevalence of sphenoid sinus agenesis in adults: a CT scan study. B-ENT 2010;6(3):167-9.

24) Kandogan T, Dalgic A, Mollamehmetoglu H, Esen O. Combined aplasia of sphenoid, frontal, and maxillary sinuses with hypoplasia of the ethmoid sinus. Iran Red Crescent Med J 2013;15(1):13-4.

25) Aydinlioğlu A, Erdem S. Maxillary and sphenoid sinus aplasia in Turkish individuals: a retrospective review using computed tomography. Clin Anat 2004;17(8):618-22.

26) Cakur B, Sümbüllü MA, Yılmaz AB. A retrospective analysis of sphenoid sinus hypoplasia and agenesis using dental volumetric CT in Turkish individuals. Diagn Interv Radiol 2011;17(3):205-8. 